\title{
ОСОБЕННОСТИ ПСИХОЭМОЦИОНАЛЬНОЙ СФЕРЫ ПОДРОСТКОВ С АРТЕРИАЛЬНОЙ ГИПЕРТЕНЗИЕЙ И ОЖИРЕНИЕМ
}

\author{
Карагулова З.А., Устинова Н.Г.
}

ФГБУ «Национальный медицинский исследовательский чентр им. В.А. Алмазова» Минздрава РФ (генеральный директор - академик РАН Шляхто Е.В.), Санкт-Петербург

\begin{abstract}
АКтУАЛЬНОСТь: в последние годы внимание детских врачей к артериальной гипертензии (АГ) вызвано тем,что эссенциальная гипертензия помолодела и чаще встречается у детей и подростков. Подростковый возраст называют «эмоциональным стрессом пубертата».Подростки сверхвозбудимы, легко ранимы, непредсказуемы, у них снижен инстинкт самосохранения-они не задумываются о своем здоровье. Повышенные эмоциональные нагрузки,сочетаясь с индивидуальными психологическими особенностями личности,увеличивают вероятность неблагоприятного влияния на психическое и физическое здоровье подростков.Зная психологические особенности личности можно говорить об ее адаптивности и стрессоустойчивости,прогнозировать развитие и течение заболеваний, а также отношение к процессу лечения.
\end{abstract}

ЦЕЛЬ: изучить особенности психоэмоциональной сферы подростков с артериальной гипертензией и ожирением.

ПАЦИЕНТЫ И МЕТОДЫ: вКлючено 30 подростков от 11 до 17 лет (73\% мальчиков и 27\% девочек).С эссенциальной АГ(ЭГ)-19(63\%),с вторичной АГ(ВГ)-6(20\%),с лабильной АГ(ЛГ)-5(17\%) подростков. Ожирение выявлено у 16(57\%). Исследование включало:клиническое наблюдение,беседу,анализ истории болезни,анкетирование по психодиагностическим тестам:Индивидуально-типологический опросник Л.Н.Собчик (ИТО); Госпитальная шкала тревоги и депрессии; Русскоязычная версия краткого опросника восприятия болезни Е.Бродбент.

PЕзУЛЬТАТЫ: состояние нервно-психического напряжения (дезадаптации)-у 16(53,3\%).Из них у двоих-высокая степень дезадаптации по 3 шкалам:экстраверсии,агрессивности и спонтанности. Выявлена тенденция к повышению показателей тревожности,агрессивности и интровертированности у подростков с ЭГ и ЛГ в сравнении с ВГ. У подростков с ЭГ выраженный эмоциональный ответ на болезнь-она их раздражает,расстраивает или пугает.А при ЛГ эмоциональный ответ минимальный, что,возможно,связано с отрицанием наличия болезни и может стать причиной игнорирования рекомендаций врача по изменению питания и образа жизни. Также выявлено:чем выше уровни спонтанности и ригидности подростков-тем достоверно( $p=0,032$ и 0,005 соответственно) выше показатели систолического артериального давления (САД). Значит,эти подростки более возбудимы, импульсивны, поведение их может быть непредсказуемым,они с трудом приспосабливаются к новому, не хотят пробовать иные способы поведения, кроме устоявшихся. Подростки с такими чертами характера более склонны к формированию высоких цифр САД.При анализе взаимосвязи психологических особенностей подростков и массы тела оказалось:чем больше масса тела-тем достоверно $(\mathrm{p}=0,04)$ меньше показатель личностной тревожности. Вероятно,срабатывают механизмы психологической защиты и подросток перестает тревожиться по поводу лишнего веса и его последствий. Также оказалось:чем больше масса тела-тем достоверно(р=0,009) выше показатель ригидности.Подростки с ожирением имеют стойкие,ригидные,трудно поддающиеся коррекции установки и привычки,в т.ч.по питанию и образу жизни. Ригидность снижает их адаптивность и стрессоустойчивость.

ВЫВОДЫ: психологические особенности,обнаруженные у подростков с АГ (ригидность,спонтанность) и ожирением (ригидность и низкая тревожность) могут проявляться в виде игнорирования врачебных рекомендаций по поводу нормализации образа жизни и питания,тем самым способствуя развитию заболевания и усложняя процесс лечения. 